\title{
Prototype Alat Penyiraman Air dan Nutrisi Otomatis Pada Proses Pembenihan Buah Naga Dengan Modul Nodemcu
}

\author{
Automatic Water and Nutrition Sprinkling Prototype For Dragon Fruit Hatchery with \\ Nodemcu Module
}

\author{
Rizky Arbilah*1, Kusnadi², Wanda Ilham ${ }^{3}$ \\ ${ }^{1,2,3}$ Program Studi Ilmu Komputer, Fakultas Eksakta, Universitas Catur Insan Cendekia \\ e-mail:*11rizkyarbilah45@gmail.com, ${ }^{2}$ kusnadi@cic.ac.id, ${ }^{3}$ wandailham99@gmail.com
}

\begin{abstract}
Abstrak
Budidaya buah naga pada saat ini sedang berada pada masa popularitas yang dahsyat karena banyaknya manfaat dari buah itu sendiri. Berbicara tentang budidaya maka tidak akan terlepas dengan adanya proses pembenihan dimana bibit tanaman tidak langsung ditanam pada lahan perkebunan melainkan dipisahkan pada tempat terpisah. Penyiraman secara manual dapat mengganggu keefesienan waktu, tenaga dan sumber daya manusia yang menimbulkan potensi permasalahan. Dari permasalah tersebut memunculkan gagasan untuk membuat sistem penyiraman otomatis dan sistem kendali untuk membantu proses pembenihan buah naga. Perakitan alat ini memanfaatan sensor kelembaban sebagai pengukur kelembaban tanaman dan real time clock (RTC) sebagai pengatur waktu penyiraman yang akan dikontrol oleh modul nodemcu sebagai microcontroller. Dengan ditunjang oleh sistem kendali melalui aplikasi telegram yang terhubung dengan microcontroller sehingga kita bisa mengendalikan alat tersebut dari jarak jauh dan meringankan pekerjaan proses pembenihan buah naga. Hasil pengujian dari perakitan alat ini ialah sebuah otomatisasi pada alat penyiraman air berdasarkan kelembaban tanah dan nutrisi berdasarkan waktu yang telah ditentukan dengan sistem kendali sebagai alat penunjang untuk mengendalikan alat dari jarak jauh.
\end{abstract}

Katakunci: penyiraman otomatis, modul nodemcu, sensor kelembapan, RTC, buah naga

\begin{abstract}
Abstrack
Dragon fruit cultivation is currently in a period of tremendous popularity because of the many benefits of the fruit itself. Speaking of cultivation, it will not be separated by the process of hatching in which plant seeds are not directly planted on plantation land but are separated in separate places. Manual watering can disrupt the efficiency of time, energy and human resources, which can lead to potential problems. From these problems led to the idea to create an automatic watering system and control system to help the process of hatching dragon fruit. The assembly of this tool utilizes a humidity sensor as a measure of plant humidity and real time clock (RTC) as a watering timer that will be controlled by the nodemcu module as a microcontroller. Supported by a control system through a telegram application that is connected to the microcontroller so that we can control the device remotely and ease the work of the dragon fruit hatchery process. The test results of the assembly of this tool is an automation of the watering device based on soil moisture and nutrients based on a predetermined time with the control system as a support for controlling the device remotely.
\end{abstract}

Keyword: : Automatic Watering, Nodemcu Module, Humidity Sensor, RTC, Dragon Fruit

\section{PENDAHULUAN}

Tanaman adalah sebuah tumbuhan yang dapat dibudidaya dan memiliki manfaat tersendiri baik itu tanaman hias sayuran, buah, ataupun yang lainnya. Budidaya pada tanaman yang menghasilkan buah menjadi salah satu peluang yang menjanjikan karena buah sudah menjadi kebutuhan pokok manusia untuk menambah kan nutrisi dan vitamin untuk tubuh. Komoditas buah naga pada saat ini sedang berada pada masa popularitas yang dahsyat. Selain karena dari bentuk dan namanya yang unik buah naga pun memiliki banyak manfaat untuk 
kesehatan. Hal itu membuat sebagian tukang kebun memanfaatkan peluang tersebut untuk membudidaya buah naga. Berbicara tentang budidaya maka tidak akan terlepas dengan adanya proses pembenihan dimana bibit tanaman tidak langsung ditanam pada lahan perkebunan. Tetapi, pembenihan dilakukan ditempat terpisah baik menggunakan polybag ataupun wadah dalam jenjang waktu tertentu.

Penyiraman secara manual dapat mengganggu keefesienan waktu, tenaga dan sumber daya manusia. Ketidak efesienan tersebut kadang proses pembenihan terabaikan dan tak terurus sehingga masalah dalam kelebihan dan kekurangan air atau nutrisi dapat menyebabkan kematian pada bibit buah naga itu sendiri, Sehingga menimbulkan potensi kerugian pada tukang kebun tanaman tersebut. Pada Kebun buah naga Desa Winduhaji, lahan perkebunan dan lahan pembenihan tidak menyatu melainkan terpisah kurang lebih berjarak 100 meter sehingga terbatasnya tukang kebun dalam proses pemeliharaan kebun buah naga dan lahan pembibitan membuat salah satu lahan tidak terurus terutama lahan pembenihan. Pekembangan teknologi yang sangat pesat menjadi alasan akan pentingnya kolaborasi antara dunia perkebunan dan dunia teknologi. Sehingga perkembangan teknologi tersebut diharapkan dapat meningkangkatkan hasil perkebunan terutama dalam hal ini proses budidaya buah naga, Penyiraman otomatis menggunakan microcontroller adalah salah satu implementasi dari perkembangan tenologi yang dapat mempermudah, dan mengefisienkan setiap kegiatan yang dilakukan.

Dalam penelitian ini, penulis akan membangun sebuah Prototype sistem penyiraman air dan nutrisi pada pembenihan buah naga. Prototype yang dibangun ini berfungsi untuk membantu tukang kebun dalam membudidaya buah naga dimana tukang kebun tidak terlalu disibukan dengan mengurus proses pembenihan dan mengurus lahan perkebunan namun bisa melakukan salah satunya dengan memonitoring dan mengendalikannya dari jauh yaitu pada proses pembenihan. Penelitian ini akan melakukan penyiraman air berdasarkan tingkat kelembaban tanah serta penyiraman nutrisi berdasarkan penjadwalan waktu. Dimana penyiraman nutrisi dilakukan sesuai waktu yang dikehendaki menggunakan RTC yang kemudian diolah oleh microcontroller. Sedangkan penyiraman air akan dilakukan sesuai tingkat kelembaban yang diukur oleh sensor kelembaban tanah yang mempunyai dua probe untuk melewatkan arus dalam tanah yang kemudian membaca resistensinya untuk mendapatkan nilai kelembaban berupa data analog hasil dari data fisik yang dirubah oleh sensor. Semakin banyak air membuat tanah lebih mudah untuk menghantarkan listrik sehingga resistensi kecil, sedangkan sedikit air dalam tanah membuat tanah lebih sulit untuk menghantarkan listrik sehingga resistensi besar, semakin lembab kondisi tanah semakin besar nilai analog pada sensor[1]. Nilai sensor tersebut yang kemudian diolah oleh microcontroller sebagai pemberi intruksi untuk menyalakan pompa sehingga melakukan proses penyiraman. Oleh karena itu dalam penelitian ini penulis akan membuat judul "Prototype Penyiraman Air Dan Nutrisi Otomatis Pada Proses Pembenihan Buah Naga Menggunakan Modul NodeMCU (Studi Kasus : Lahan Pembenihan Buah Naga Desa Winduhaji)".

Pada tahun 2017 peneliti [2] menyatakan pemanfaatan microcontroller sebagai salah satu perkembangan teknologi sebagai kontrol sistem otomatis yang dapat mempermudah setiap kegiatan yang ingin dilakukan guna mengikuti perkembangan teknologi yang berkembang saat ini. Penelitian terdahulu hanya berfokus pada penyiraman air saja dan kebanyakan hanya memanfaatkan sensor kelembaban saja. Pada penelitian[3], akan menambahkan penyiraman nutrisi dengan memanfaatkan RTC (Real Time Clock) untuk penjadwalan. Sehingga penyiraman tidak hanya menyiram air saja tetapi ada tambahan nutrisi untuk meningkatkan kualitas proses pembenihan tanaman. Penelitian ini pun berbasis IoT dimana terdapat sistem monitoring dan kendali melalui telegram untuk mempermudah tukang kebun dalam proses monitoring dan mengendalikan alat dari jarak jauh. 


\section{METODE PENELITIAN}

Penelitian ini secara umum merupakan penelitian yang bertujan untuk menghasilkan suatu produk yaitu Prototype Sistem Penyiraman air dan nutrisi otomatis menggunakan modul NodeMCU. Sesuai dengan tujuan penelitan yang dikemukanan diatas, maka metode yang cocok untuk digunakan adalah metode penelitian dan pengembangan sistem yang dikenal dengan istilah RAD (Rapid Aplication Development). Rapid Aplication Development (RAD) adalah sebuah proses perkembangan perangkat lunak sekuensial linier yang menekankan siklus perkembangan dalam waktu yang singkat[4]. Dalam pengembangan sistem informasi normal, memerlukan waktu minimal 180 hari, namun dengan menggunakan metode RAD, sistem dapat diselesaikan dalam waktu 30-90 hari[5]. Model Pengembangan Sistem RAD memiliki tahapan seperti gambar 1.

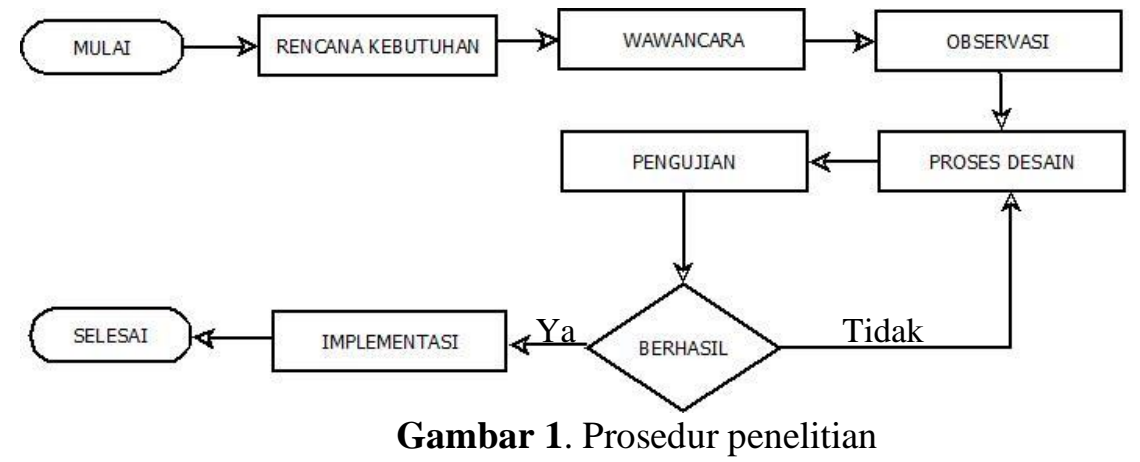

a. Rencana Kebutuhan (Requirement Planning)

Pada tahap ini, Peneliti dan Pihak Perkebunan melakukan pertemuan (wawancara) untuk mengidentifikasi tujuan dari sistem dan kebutuhan informasi untuk mencapai tujuan[6]. Pada tahap ini merupakan hal terpenting yaitu adanya keterlibatan dari kedua belah pihak. Pada tahap ini juga peneliti melakukan observasi lahan secara langsung untuk kemudian dilakukan perancangann sistem Penyiraman air dan nutrisi otomatis.

b. Proses Desain Sistem (Design System)

Pada tahap ini keaktifan Pihak Perkebunan yang terlibat menentukan untuk mencapai tujuan karena pada proses ini melakukan proses desain dan melakukan perbaikan-perbaikan apabila masih terdapat ketidak sesuaian desain antara Pihak Perkebunan dan peneliti[7]. Pihak Perkebunan dapat langsung memberikan komentar apabila terdapat ketidak sesuaian pada desain, merancang sistem dengan mengacu pada dokumentasi kebutuhan user yang dibuat pada tahap sebelumnya. Keluaran dari tahapan ini adalah gambaran umum sistem, diagram blok, perancangan alat, perancangan microcontroller, dan Flowchart cara kerja alat. Diagram alir yang ditunjukan oleh Gambar 2 menunjukan cara kerja sistem penyiraman air otomatis dimana sensor kelembaban akan membaca nilai A0 dalam hal itu adalah nilai analog yang terdeteksi oleh sensor yang kemudian akan di seleksi apabila nilai tersebut lebih kecil sama dengan 700 maka kondisi tersebut kering dan nodeMCU akan mengirim perintah ke relay untuk menyalakan pompa air, sedangkan apabila nilai lebih besar dari 700 maka kondisi tersebut kering dan nodeMCU akan mengirimkan perintah ke relay untuk mematikan pompa tersebut. 


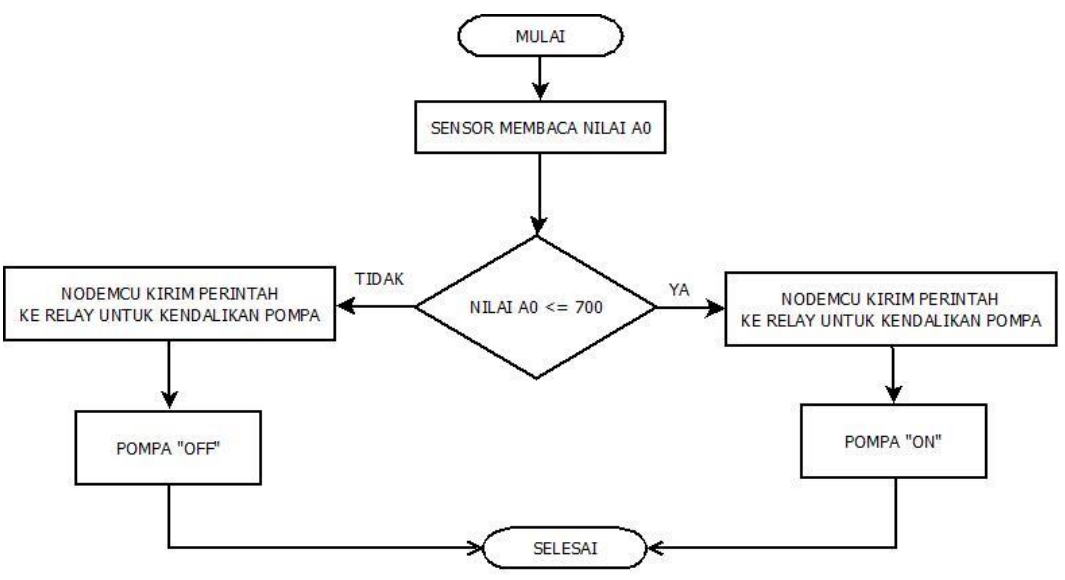

Gambar 2. Flowchart Sistem otomatisasi Penyiraman Air

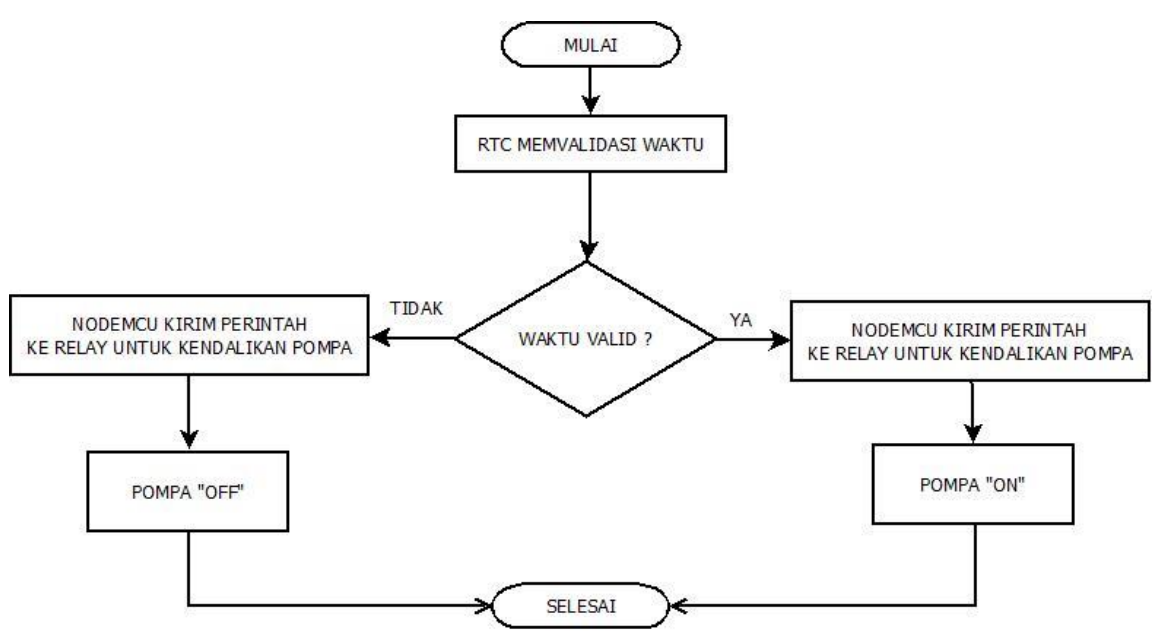

Gambar 3. Flowchart Penyiraman Nutrisi

Diagram alir yang ditunjukan oleh Gambar 3 menunjukan cara kerja sistem penyiraman nutrisi otomatis dimana RTC akan memvalidasi waktu, jika waktu valid maka nodeMCU akan mengirmkan perintah ke relay untuk menyalakan pompa dan jika waktu tidak valid maka nodeMCU akan mengirimkan perintah ke relay untuk mematikan pompa.

Diagram alir yang ditunjukan oleh Gambar 4 menunjukan cara kerja sistem kendali pada proses penyiraman dimana user akan mengirmkan perintah on/off ke telegram bot yang kemudian akan melalui proses seleksi apakah perintah benar atau tidak. Jika perintah benar maka nodeMCU akan mengendalikan relay on/off terhadap perangkat dan kemudian bot akan menampilkan pesan balasan. Sedangkan jika perintah salah, maka user akan menerima balasan gagal dan bot menampilkan pesan balasan. 


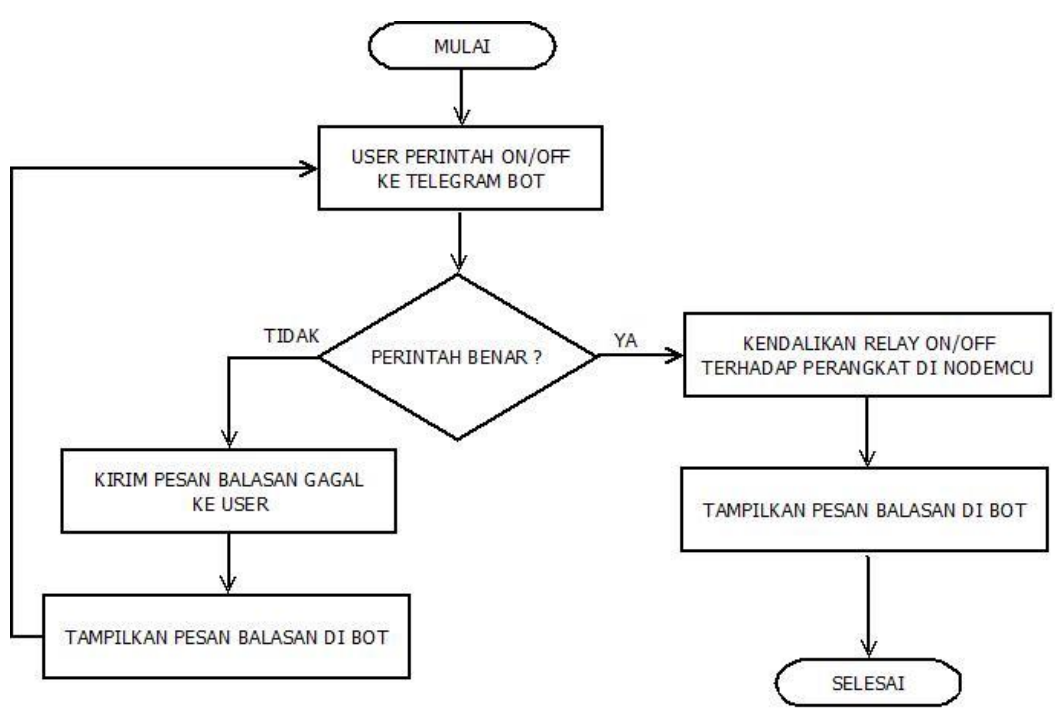

Gambar 4. Flowchart Sistem kendali

c. Implementasi (Implementation).

Tahapan ini adalahan tahapan dimana peneliti akan membuat sistem Penyiraman air dan nutrisi otomatis. Sebelum diimplementasikan, terlebih dahulu dilakukan proses pengujian terhadap sistem tersebut apakah ada kesalahan atau tidak. Pada tahap ini Pihak Perkebunan biasa memberikan tanggapan akan sistem yang sudah dibuat serta mendapat persetujuan mengenai sistem tersebut[8].

\section{HASIL DAN PEMBAHASAN}

Rancangan Skematis Hardware

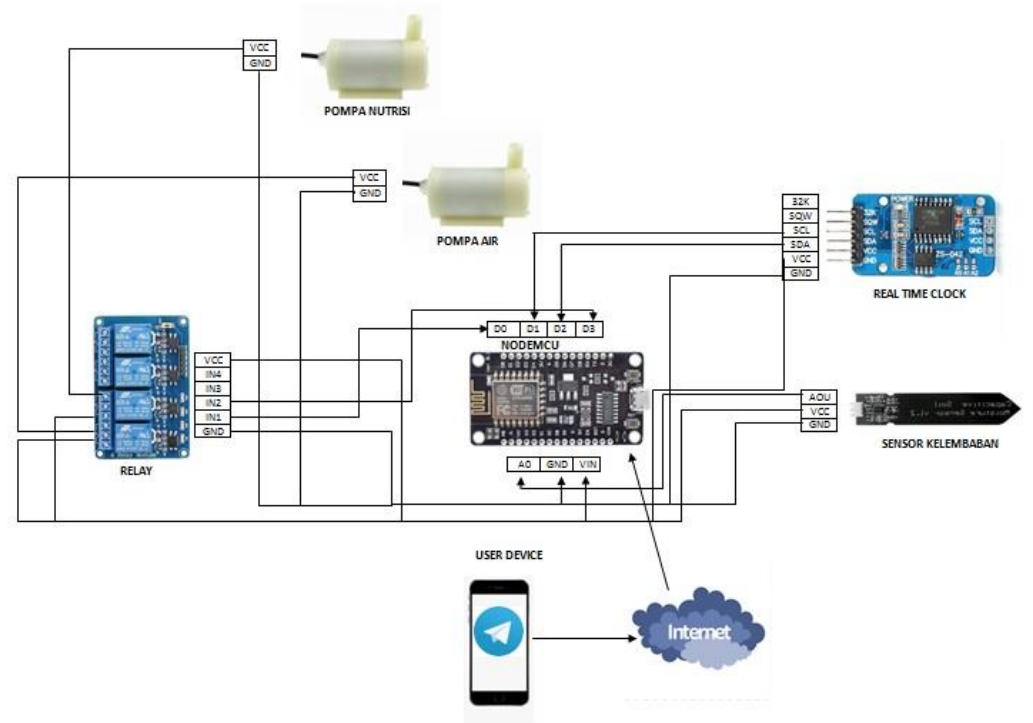

Gambar 5. diagram blok sistem penyiraman otomatis dan kendali

Diagram blok diatas menggambarkan cara kerja komunikasi antar perangkat dalam monitoring dan mengendalikan multi perangkat dengan penjelasan sebagai berikut:

1. Pengguna mengakses aplikasi TelegramBot melalui device. 
2. TelegramBot dengan NodeMCU saling terhubung melalui internet dan saling berkomunikasi melalui token TelegramBot yang sudah dikonfigurasi ke NodeMCU.

3. NodeMCU berfungsi sebagai pengendali utama dari sistem ini dimana perintah dari TelegramBot diterima oleh NodeMCU yang kemudian diteruskan ke relay untuk mengendalikan perangkat.

4. RTC berfungsi sebagai penyimpan data waktu secara real time (detik, menit, jam, hari, tanggal, bulan, dan tahun) yang digunakan oleh NodeMCU untuk mengendalikan perangkat secara otomatis dengan penjadwal.

5. Sensor kelembaban berfungsi untuk mencari nilai kelembaban tanah yang kemudian data tersebut dikirim ke NodeMCU untuk diolah.

6. Relay sebagai saklar arus listrik dengan membuka dan tutup gerbang arus listrik untuk mengaliri pompa sesuai perintah NodeMCU.

7. Pompa sebagai output dimana pompa menunggu aliran listrik dari relay untuk bekerja.

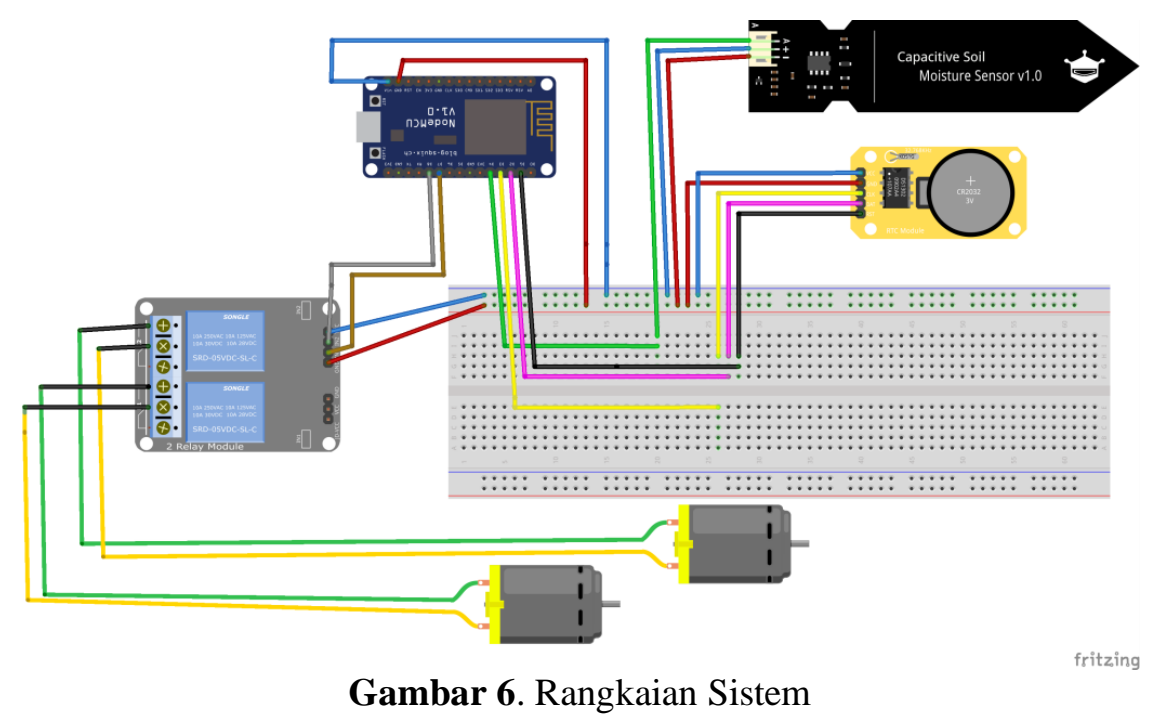

Berdasarkan gambar 6, Pada alat ini mengulas tentang bagaimana alat ini melakukan penyiraman otomatis menggunakan sensor kelembaban sebagai pendeteksi kelembaban dan RTC sebagai pengatur jadwal penyiraman dengan pengendali NodeMCU. Dimana sensor kelembaban tanah memiliki rentang jangkauan pengukuran kelembaban tanah 0-100 \% dengan menggunakan metode kalibrasi gravimetri Dengan rumus.

Keterangan :

$$
\text { KAT }=(\text { Mtb }- \text { Mtk }) \text { Mtb } \times 100 \%
$$
KAT : Kadar Air Tanah
Mtb : Massa Tanah Basah
Mtk : Massa Tanah Kering

Dari rangkaian sistem di atas menggambarkan cara kerja komunikasi antar perangkat dalam mengendalikan perangkat dengan penjelasan berikut:

1. Koneksi NodeMCU ESP8266 dengan RTC DS3231

Tabel 1. Koneksi NodeMCU ESP8266 dengan RTC DS3231

\begin{tabular}{lll}
\hline \multicolumn{1}{c}{ NodeMCUESP8266 } & RTC-DS3231 & \multicolumn{1}{c}{ Keterangan } \\
\hline Pin D1 & SDA & Pin untuk Serial Data pin (I2C interface) \\
\hline Pin D2 & SCL & Pin untuk Serial Clock pin (I2C interface) \\
\hline GND & GND & Pin untuk sumber daya arus negatif \\
\hline Vin & VCC & Pin untuk sumber daya arus positif \\
\hline
\end{tabular}


2. Koneksi NodeMCU ESP8266 dengan Relay

Tabel 2. Koneksi NodeMCU ESP8266 dengan Relay

\begin{tabular}{lll}
\hline \multicolumn{1}{c}{ NodeMCUESP8266 } & Relay & \multicolumn{1}{c}{ Keterangan } \\
\hline Pin D0 & IN 1 & Pin untuk mengontrol kendali chanel 1 pada relay \\
\hline Pin D3 & IN 2 & Pin untuk mengontrol kendali chanel 2 pada relay \\
\hline GND & GND & Pin untuk sumber daya arus negatif \\
\hline Vin & VCC & Pin untuk sumber daya arus positif \\
\hline
\end{tabular}

3. Koneksi NodeMCU ESP8266 dengan Soil Moisture V.1.2

Tabel 3. Koneksi NodeMCU ESP8266 dengan Soil Moisture V.1.2

\begin{tabular}{lll}
\hline NodeMCUESP8266 & Soil Moisture V.1.2 & Keterangan \\
\hline Pin A0 & AOU pin & $\begin{array}{l}\text { Pin untuk membaca nilai kelembaban } \\
\text { tanah. }\end{array}$ \\
\hline GND & GND & Pin untuk sumber daya arus negatif \\
\hline Vin & VCC & Pin untuk sumber daya arus positif \\
\hline
\end{tabular}

4. Koneksi Pompa dengan Relay

Tabel 4. Koneksi Pompa dengan Relay

\begin{tabular}{lll}
\hline NodeMCUESP8266 & Relay & Keterangan \\
\hline GND & NO (normally Open) & $\begin{array}{l}\text { Pin untuk sumber daya arus } \\
\text { negative }\end{array}$ \\
\hline Vin & NC (normally Closed) & Pin untuk sumber daya arus positif \\
\hline
\end{tabular}

\section{Tampilan Hardware dan Software}

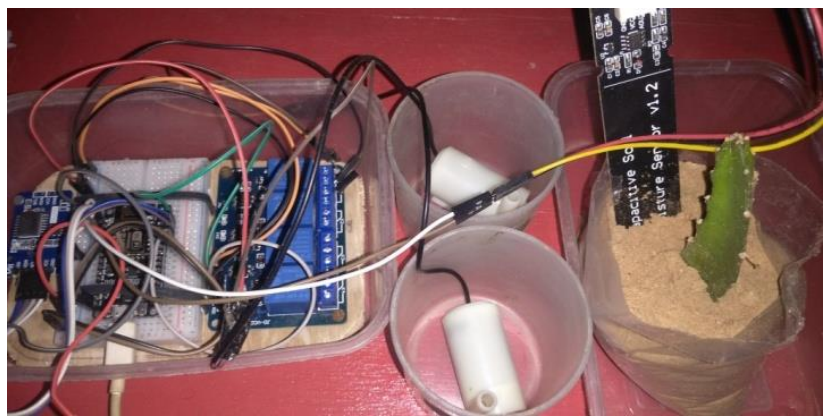

Gambar 7. Tampilan Hardware

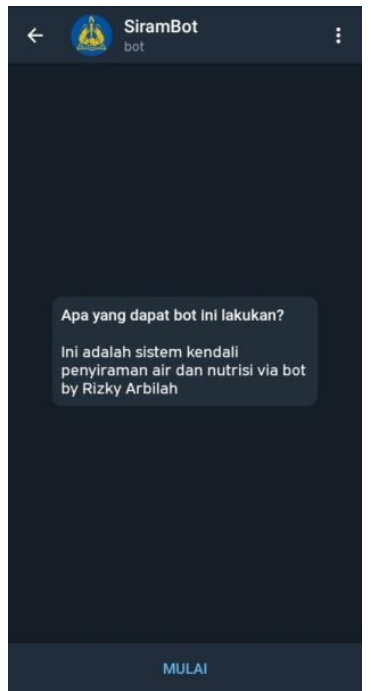

Gambar 8. Tampilan Software

Pada Gambar 7 merupakan prototype alat penyiraman otomatis yang telah selesai dirancang dan siap digunakan. Sedangkan pada gambar 8 merupakan tampilan awal bot yang telah dibuat dengan nama SiramBot. 


\section{Pengujian}

Sistem Kendali melalui SiramBot pada Telegram

1. Mengirim perintah "/start"

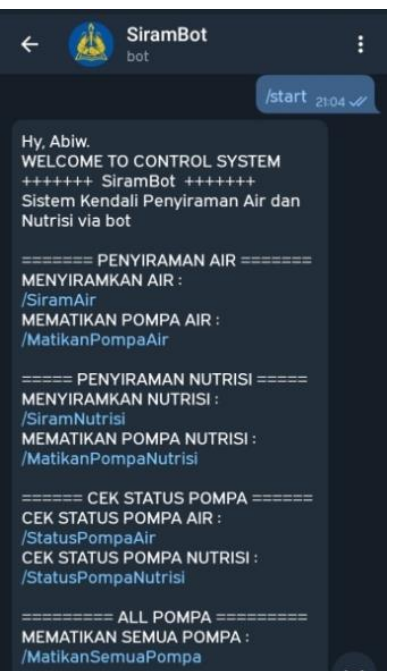

Gambar 9. Perintah start bot

Pada dinding pesan SiramBot di Telegram, sudah terkirim perintah "/start" yang kemudian bot menjawab perintah tersebut dengan menampilkan informasi dan menu perintah untuk melakukan perintah berikutnya.

2. Mengirim Perintah “/SiramAir" dan "/MatikanPompaAir"

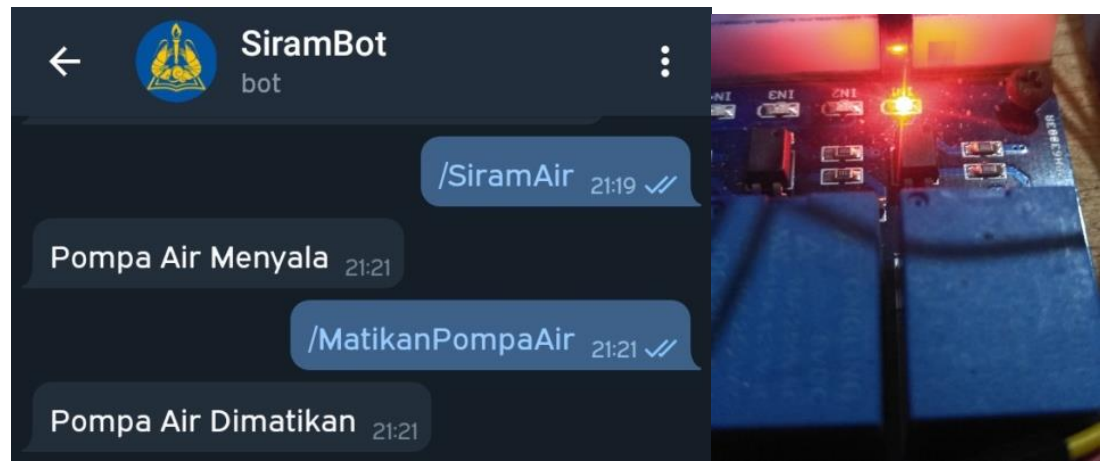

Gambar 10. Perintah Siram Air dan Matikan

Pompa Air akan menyala ketika perintah "SiramAir" dikirimkan melalui Sirambot ditandai dengan lampu channel 1 relay pada gambar sebelah kanan menyala, dan akan mati kembali setelah diberi perintah "/MatikanPompaAir".

3. Perintah "/SiramNutrisi" dan "/MatikanPompaNutrisi"

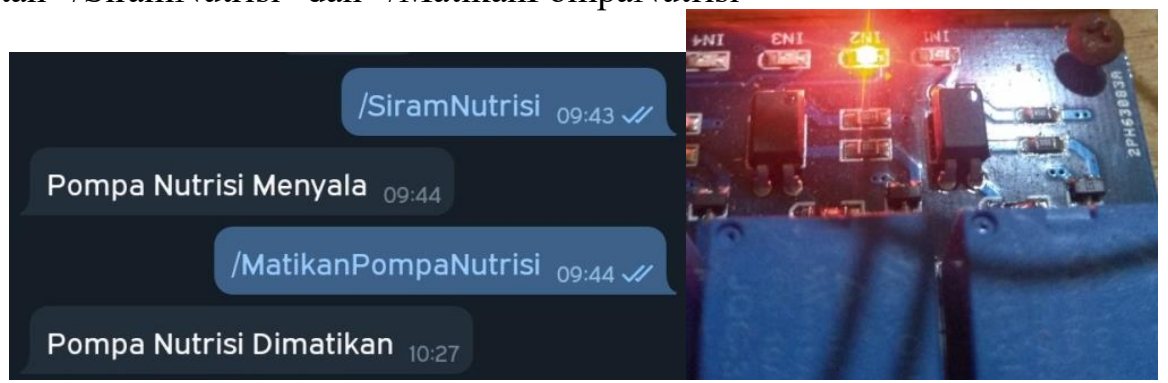

Gambar 11. Perintah Siram Nutrisi dan Matikan 
Pompa Nutrisi akan menyala ketika perintah "SiramNutrisi” dikirimkan melalui Sirambot ditandai dengan lampu channel 2 relay pada gambar sebelah kanan menyala, dan akan mati kembali setelah diberi perintah "/MatikanPompaNutrisi".

4. Perintah "/MatikanSemuaPompa"

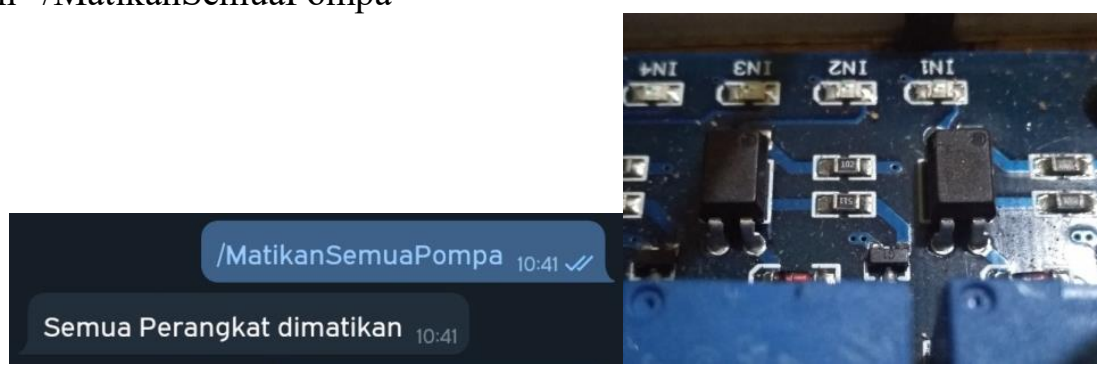

Gambar 12. Perintah Matikan Semua

Ketika pompa keduanya sedang dalam kondisi menyala, lalu ingin mematikan keduanya bisa menggunakan perintah "/MatikanSemuaPerintah" tanpa harus mematikan Pompa satu persatu.

5. Memonitoring Status kedua Pompa dengan perintah "/StatusPompaAir" dan "StatusPompaNutrisi"

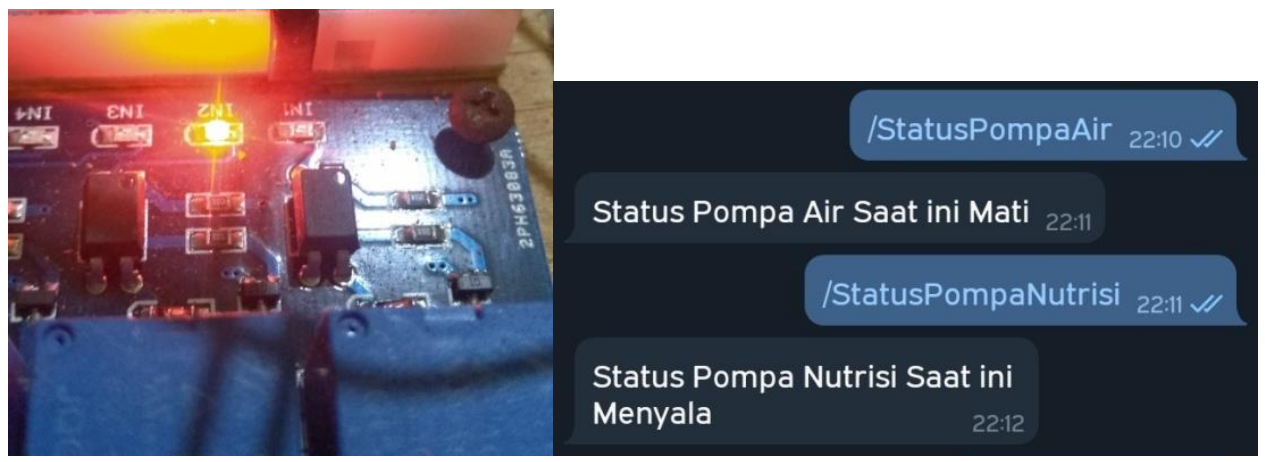

Gambar 13. Cek Status Kedua Pompa

Dalam keadaan seperti pada gambar sebelah kiri ketika ingin mengetahui status kondisi pompa baik air maupun nutrisi, bisa menggunakan perintah "StatusPompaAir" dan "StatusPompaNutrisi" maka jika perintah sudah dikirim, akan ada balasan informasi sesuai Keadaan status pompa pada saat itu juga seperti contoh pada gambar 13.

\section{Sistem otomatisasi penyiraman Air dan Nutrisi}

Dalam otomatisasi penyiraman Air akan dikontrol oleh sensor kelembaban yang menentukan kondisi tanah basah atau kering sedangkan untuk penyiraman nutrisi akan dikontrol oleh RTC sebagai penjadwal waktu, ketika waktu yang telah diatur tiba maka pompa nutrisi akan menyala selama 1 menit untuk menyiram. 
1. Penjadwalan dengan menggunakan Real Time Clock(RTC)

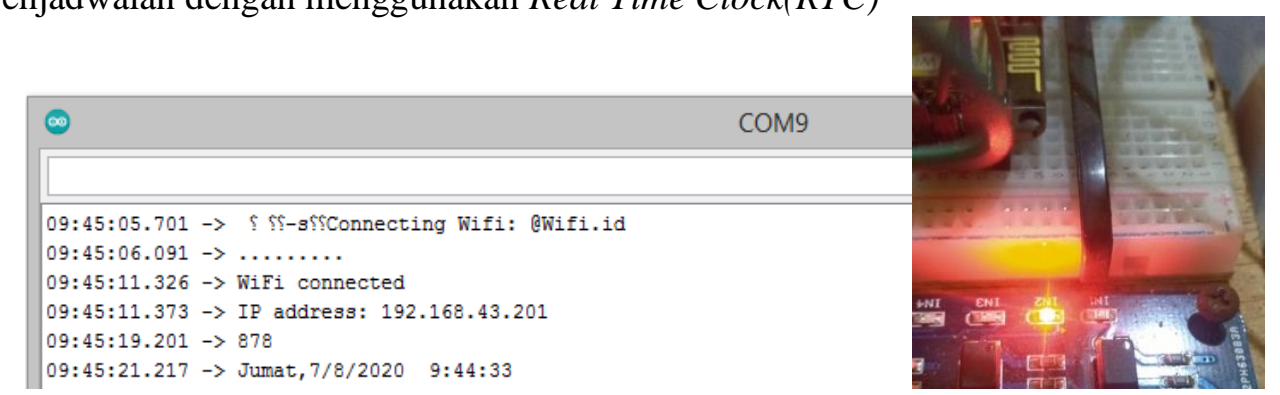

Gambar 14. Pompa Nutrisi Menyala Otomatis

Dalam penjadwalan yang telah diatur, pompa akan menyiram nutrisi otomatis pada hari jum'at jam 9:44 seperti yang terlihat pada gamabar 14 dimana lampu relay menyala menandakan aliran listrik telah dibuka dan mengalir ke pompa sehingga pompa nutrisi menyala.

2. Penyiraman Air berdasarkan Kelembaban tanah.

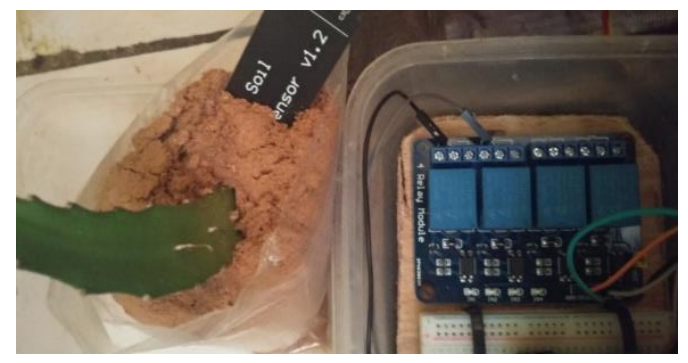

Gambar 15. Kondisi Basah

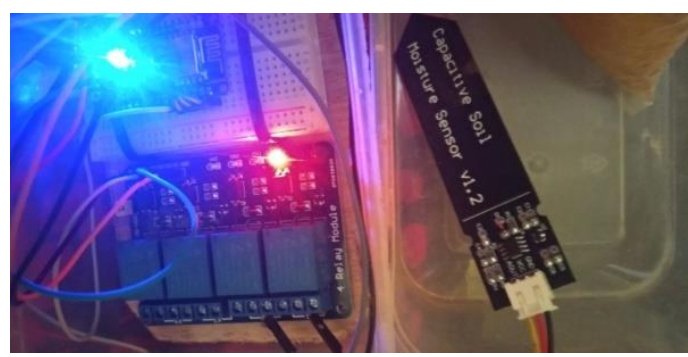

Gambar 16. Kondisi Kering

Pada gambar 15 tanah dalam kondisi basah sehingga lampu relay tidak menyala dalam artian pompa pun tidak akan menyala. Sedangkan pada gambar 16 ketika sensor dalam keadaan kering, lampu relay menyala sehingga pompa pun menyala karena arus listrik mengalir.

\section{KESIMPULAN}

Berdasarkan kegiatan penelitian yang telah penulis lakukan, maka ada beberapa kesimpulan yang dapat diambil, diataranya adalah pemanfaatan Microcontroller, Sensor dan komponen penunjang lainnya dapat saling berintegritaskan sehingga alat penyiraman otomatis beserta sistem kendali dapat terancang. Perancangan sistem otomatisasi dan kendali dapat memudahkan pengguna untuk memonitoring dan mengendalikan alat dari jarak jauh. 
Penyiraman manual akan tergantikan oleh alat penyiraman otomatis karena beberapa kelebihan yang dimiliki alat penyiraman otomatis.

\section{SARAN}

Alat penyiraman air dan nutrisi otomatis tentu tidak terlepas dari beberapa kekurangan. Oleh sebab itu, untuk pengembangan selanjutnya yang lebih baik, penulis menyarankan beberapa hal diantaranya adalah :

1. Perlu adanya monitoring kerusakan pada alat sehingga maintenance pada alat akan lebih mudah.

2. Daya atau tegangan listrik pada pompa lebih baik menggunakan stopkontak untuk meminimalisir kehabisan daya.

3. Dari segi tampilan sistem kendali pada telegram sangat sederhana, pembaharuan software sistem kendali yang lebih elegan.

4. Diperlukan adanya modifikasi lanjutan agar sistem kendali dapat menjadi lebih mudah lagi dan dapat dioperasikan oleh pengguna awam sekalipun.

Diperlukana adanya pengembangan aplikasi sehingga mampu merubah penjadwalan secara manual tanpa meng-upload ulang program.

\section{DAFTAR PUSTAKA}

[1] H. Husdi, "Monitoring Kelembaban Tanah Pertanian Menggunakan Soil Moisture Sensor Fc-28 Dan Arduino Uno," Ilk. J. Ilm., vol. 10, no. 2, pp. 237-243, 2018, doi: 10.33096/ilkom.v10i2.315.237-243.

[2] R. B. Agung, M. Nur, and D. Sukayadi, "Prototype Aplikasi Penyiraman Tanaman Menggunakan Sensor Kelembapan Tanah Berbasis Micro Controller ATMEGA 328," cerita, vol. 5, no. 1, pp. 97-106, 2019.

[3] S. B. Mursalin, H. Sunardi, and Z. Zulkifli, "Sistem Penyiraman Tanaman Otomatis Berbasis Sensor Kelembaban Tanah Menggunakan Logika Fuzzy," J. Ilm. Inform. Glob., vol. 11, no. 1, pp. 47-54, 2020, doi: 10.36982/jig.v11i1.1072.

[4] Y.- Firmansyah, R. Maulana, and D. Arivianti, "Prototipe Sistem Informasi Pelelangan Barang Berbasis Web Sebagai Media Pengolah Informasi Data Pelelangan," $J$. Khatulistiwa Inform., vol. 7, no. 2, pp. 134-140, 2019, doi: 10.31294/jki.v7i2.6655.

[5] J. R. Sagala, "Model Rapid Application Development (Rad) Dalam Pengembangan Sistem Informasi Penjadwalan Belajar Mengajar," J. Mantik Penusa, vol. 2, no. 1, pp. 87-90, 2018.

[6] D. S. Purnia, "Implementasi metode RAD pada Rancang Aplikasi BAN-SOS Terdistribusi Berbasis Mobile," J. IJCIT (Indonesian J. Comput. Inf. Technol., vol. 3, no. 1, pp. 71-79, 2018, doi: 10.31294/ijcit.v3i1.3761.

[7] O. I. - AMIK BSI Bekasi and G. B. A. L. - AMIK BSI Bekasi, "Metode Rapid Application Development (RAD) pada Perancangan Website Inventory PT. SARANA ABADI MAKMUR BERSAMA (S.A.M.B) JAKARTA," Evolusi J. Sains dan Manaj., vol. 6, no. 2, pp. 12-18, 2018, doi: 10.31294/evolusi.v6i2.4414.

[8] R. Rudianto, "The Implementation of the RAD model in the Development of Tender Selection Programs Using the AHP Method," J. Informatics Telecommun. Eng., vol. 3, no. 2, pp. 232-239, 2020, doi: 10.31289/jite.v3i2.3232. 